\begin{tabular}{|c|c|c|}
\hline $\begin{array}{l}\text { OPEN ACCESS } \\
\text { Vol. } 2 \text { No. 2: } 38-51 \\
\text { Tahun 2019 } \\
\text { Artikel penelitian 固 }\end{array}$ & $\begin{array}{c}\text { Eurreal Alewatiklestari } \\
\text { E-ISSN: 2598-8204 } \\
\text { http://ojs.umrah.ac.id/index.php/akuatiklestari } \\
\text { DOI: } \text { https://doi.org/10.31629/akuatiklestari.v2i2.2364 }\end{array}$ & $Q=$ \\
\hline
\end{tabular}

\title{
Analisis Kesesuaian Kawasan Wisata Pantai di Pulau Terkulai Kelurahan Senggarang Kota Tanjungpinang
}

\author{
Analysis Of Conformity The Beach Tourism Area at Terkulai Island Senggarang Village \\ Tanjungpinang City
}

Herni Eriawati ${ }^{\circledR}$, Febrianti Lestari ${ }^{1}$, Dedy Kurniawan ${ }^{1}$

${ }^{1}$ Manajemen Sumberdaya Perairan, Fakultas Ilmu Kelautan dan Perikanan, Universitas Maritim Raja Ali Haji, Tanjungpinang, Indonesia 29111

$\square$ Info Artikel:

Diterima: 29 Januari 2019

Revisi: 12 Februari 2019

Disetujui: 29 Maret 2019

Dipublikasi: 30 Mei 2019

[1] Keyword:

Kesesuaian, Daya Dukung, Wisata Pantai, Pulau Terkulai
ABSTRAK. Tujuan penelitian ini adalah untuk mengetahui potensi ekologis, tingkat kesesuaian dan daya dukung kawasan wisata pantai. Penelitian ini dilakukan dengan metode deskriptif kuantitatif. Hasil penelitian ini menunjukkan tingkat kesesuaian kawasan wisata pantai di Pulau Terkulai berdasarkan potensi ekologis yaitu kedalaman, tipe pantai, lebar pantai, material dasar perairan, kecepatan arus, kemiringan pantai, kecerahan pantai, biota berbahaya, aksesibilitas, sarana dan prasarana, penutupan lahan pantai serta ketersediaan air tawar memiliki nilai indeks kesesuaian wisata pada titik sampling I dan II yaitu 73,86\% dengan kategori sangai sesuai (S1) dan titik sampling III yaitu 68,42\% dengan kategori cukup sesuai (S2). Daya dukung kawasan pantai Pulau Terkulai untuk aktivitas wisata pantai adalah 234 jiwa dengan pemanfaatan luas area 50 m²/orang untuk waktu kunjungan selama 3 jam/orang/hari.

\begin{abstract}
The purpose of this research was to determine the ecological potential, perception and participa tion of the community and the level of suitability of coastal tourism areas and the carrying capacity of the area. This research was conducted using quantitative descriptive method. The results of this research indicate the level of suitability of coastal to urism areas in the Terkulai island based on ecological potential, depth, beach type, beach width, wate $r$ base material, current velocity, coastal slope, beach brightness, dangerous biota, accessibility, facilities and infrastructure, coastal land cover and fresh water availability has a value of the Tourism Suitability Index at the sampling points I and II which are $73.86 \%$ categorized very appropriate (S1) and the sampling point III is $68.42 \%$ categorized quite appropriate or S2. The carrying capacity of Terkulai island beach area for beach tourism activities is 234 people with the use of an area of $50 \mathrm{~m} 2 /$ per son for a visit time of 3 hours/person/day.
\end{abstract} Tanjungpinang. Jurnal Akuatiklestari, 2(2): 38-51. DOI: https://doi.org/10.31629/akuatiklestari.v2i2.2364

\section{PENDAHULUAN}

Kepulauan Riau memiliki posisi geoekonomi dan geopolitik yang sangat strategis karena berbatasan langsung dengan negara Singapura, Malaysia, Vietnam, Kamboja dan Brunei. Berdasarkan data Direktorat Pendayagunaan Pulaupulau Kecil (2012), Provinsi Kepulauan Riau memiliki 1.873 pulau-pulau kecil dengan keindahan alami yang menawan dan eksotis serta kekayaan sumberdaya alam yang melimpah yang dapat dimanfaatkan untuk kegiatan pariwisata.

Kota Tanjungpinang sebagai ibukota Provinsi Kepulauan Riau yang terletak di Pulau Bintan terdiri dari beberapa pulau diantaranya Pulau Penyengat, Pulau Dompak, Pulau Birandewa, Pulau Terkulai, Pulau Los, Pulau Basing, Pulau Paku, Pulau Sekatap dan Pulau Bayan. Koridor Pariwisata Daerah (KPD) Tanjungpinang sebagai kawasan wisata sejarah, wisata budaya, dan wisata kreatif dengan daya tarik pengunjung budaya, sejarah, kuliner, wisata mangrove, ekonomi kreatif dan island tour (BAPPEDA, 2016). Objek wisata yang berada di Kota Tanjungpinang terkenal akan sejarah dan budayanya, tidak dengan wisata baharinya. Untuk itu, island tour yang merupakan salah satu koridor pariwisata daerah sebagai dasar untuk dikembangkannya potensi yang ada di Kota Tanjungpinang.

Salah satu pulau kecil di Tanjungpinang yang memiliki potensi yaitu Pulau Terkulai yang secara administrasi termasuk wilayah Kelurahan Senggarang, Kecamatan Tanjungpinang Kota yang terletak di sebelah Barat Kota Tanjungpinang. Jarak tempuh menuju Pulau Terkulai sekitar 11 kilometer dari Pelabuhan Sri Bintan Pura sebagai pelabuhan Internasional Kota Tanjungpinang dan sekitar 6 kilometer dari Desa Busung Kabupaten Bintan. 
Berdasarkan jarak tersebut wisatawan atau nelayan yang biasanya mengunjungi Pulau Terkulai adalah masyarakat Desa Busung dan Kelurahan Senggarang. Aktivitas yang biasanya dilakukan yaitu mencari Siput Gonggong (Strombus sp.), memancing, berenang, berjemur, bersampan, snorkeling, atau hanya sekedar berlibur. Letak Pulau Terkulai pun strategis karena merupakan jalur kapal laut Kota Tanjungpinang menuju Pulau Batam dan negara Singapura. Pada jalur lintasan tersebut akan terlihat garis pantai panjang yang mengelilingi Pulau Terkulai yang menawarkan keindahan pasir putih dan degradasi warna biru lautnya yang cerah. Berdasarkan pengamatan Pulau Terkulai memiliki topografi pantai yang landai yang menyebabkan ombak laut yang tenang, pantai putih yang bersih, banyaknya pepohonan yang rindang yang dapat memberikan rasa nyaman saat berkunjung. Panorama pesisir dan lautannya membuat daya tarik tersendiri bagi pengunjung. Hal ini merupakan sebuah potensi sumberdaya alam yang dapat dimanfaatkan untuk wisata, baik fisik pantai maupun fisik perairan di Pulau Terkulai, serta peluang dalam pengembangan kawasan wisata.

Namun, potensi besar yang dimiliki PulauTerkulai saat ini belum dimanfaatkan secara optimal. Belum optimalnya kegiatan wisata pantai tersebut disebabkan kurangnya dukungan pemerintah dalam hal keterbatasan fasilitas penunjang baik dari segi aksesibilitas maupun amenitas. Fasilitas yang ada belum memadai, ditambah dengan masih rendahnya sumberdaya manusia di sekitar Pulau Terkulai sehingga belum berkembang menjadi suatu kawasan wisata pantai yang memadai. Maka, saat ini kebutuhan akan data dan informasi tentang potensi ekologi, kesesuaian kawasan wisata pantai serta daya dukung kawasan di Pulau Terkulai penting untuk dimiliki dalam penetapan suatu kawasan pantai menjadi tujuan wisata pantai dan pengembangan wisata pantai pada waktu mendatang.

\section{BAHAN DAN METODE}

\subsection{Waktu dan Tempat}

Penelitian ini dilaksanakan selama 3 bulan mulai awal April 2018 sampai awal Juli 2018 di Pulau Terkulai, Kelurahan Senggarang, Kecamatan Tanjungpinang Kota, Kota Tanjungpinang, Provinsi Kepulauan Riau. Lokasi penelitian dapat dilihat pada Gambar 1.

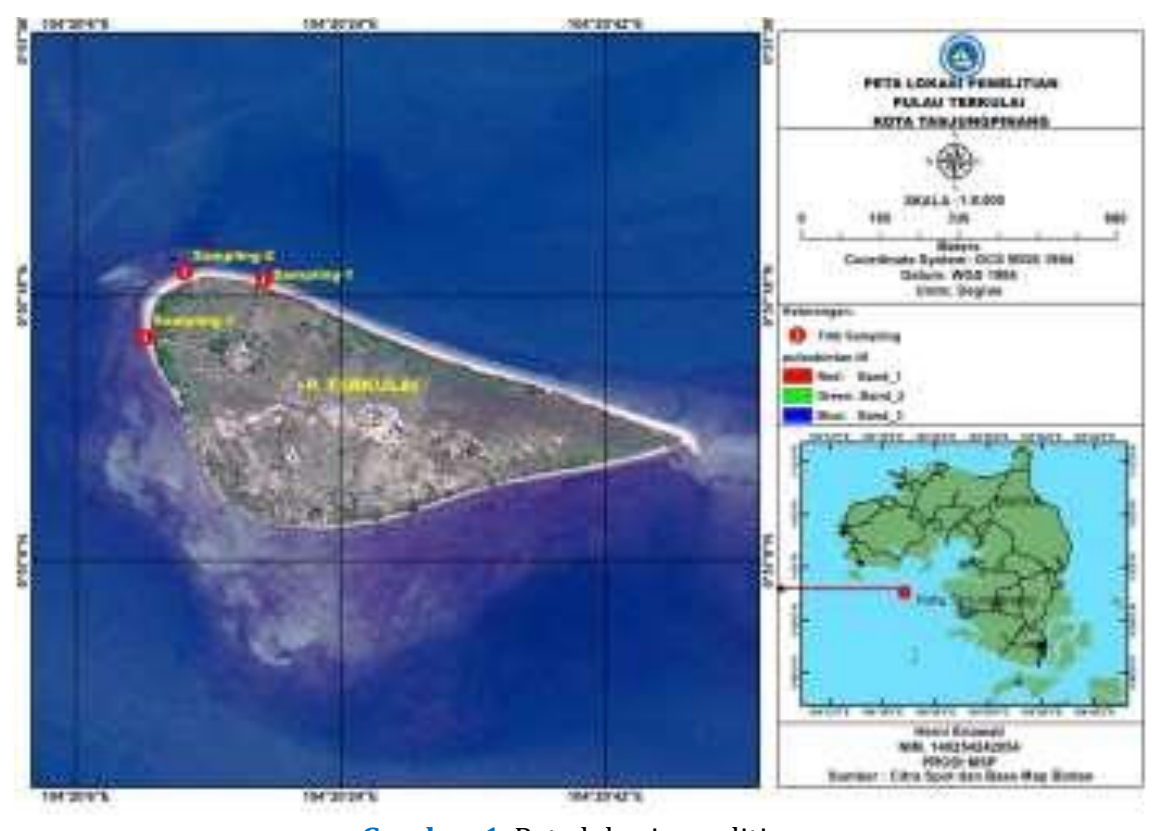

Gambar 1. Peta lokasi penelitian

Penentuan titik sampling pengamatan untuk melihat kelayakan kawasan wisata pantai Pulau Terkulai dilakukan dengan metode purposive sampling. Pertimbangan menggunakan metode ini karena purposive sampling adalah teknik pengambilan sampel sumber data dengan pertimbangan tertentu dalam hal ini berdasarkan pertimbangan kawasan pantai yang biasanya dikunjungi oleh para pengunjung untuk aktivitas wisata pantai pada 3 titik sampling tersebut.

\subsection{Alat dan Bahan}

Alat-alat yang digunakan dalam penelitian ini meliputi alat pengukuran parameter fisika dan parameter sosial masyarakat. Jenis alat yang digunakan yaitu alat tulis untuk mencatat hasil pengamatan in situ, tiang skala untuk, mengukur kedalaman, kamera sebagai dokumentasi, roll meter untuk mengukur lebar pantai, tali dan botol untuk mengukur kecepatan arus, GPS (global positioning system) untuk menentukan titik koordinat, secchi disc untuk mengukur kecerahan, laptop sebagai pengolah data, kuisioner lembar wawancara, literatur lainnya sebagai data sekunder, water pass untuk mengukur kemiringan pantai, sieve net sebagai penentuan material dasar perairan, oven untuk mengeringkan substrat, plastik sampel sebagai wadah substrat dan vegetasi, alumunium foil sebagai wadah mengeringkan substrat, timbangan analitik untuk menimbang sampel substrat, cawan petri sebagai wadah menimbang sampel susbtrat, sikat bulu untuk membersihkan sieve net, stopwatch untuk menghitung kecepatan arus. 
Bahan-bahan yang digunakan dalam penelitian meliputi bahan yang menjadi objek penelitian di lapangan dan bahan yang digunakan dalam analisis laboratorium. Bahan yang digunakan dalam penelitian ini yaitu, substrat sebai analisis fraksi substrat dan vegetasi untuk identifikasi vegetasi penutupan lahan pantai.

\subsection{Prosedur Penelitian}

\subsubsection{Potensi Ekologi}

Prosedur mengukur 12 parameter kesesuaian wisata pantai dalam menentukan potensi ekologi Pulau Terkulai tersebut diantaranya:

\section{Kedalaman}

Pengukuran kedalaman pada penelitian ini menggunakan alat rambu ukur/tiang skala. Nilai yang ditunjukkan pada tiang skala ini merupakan nilai kedalaman titik sampling penelitian dan penentuan kedalaman 10 meter dari garis pantai (Kamah et al., 2013). Pengukuran kedalaman pada masing-masing titik sampling dilakukan pengulangan 3 kali setiap jarak 10 meter tegak lurus ke arah laut.

\section{Tipe Pantai}

Penentuan tipe pantai dilakukan secara pengamatan visual, yaitu dengan mengamati jenis dan warna pasirnya (Chasanah et al., 2017; Mizan et al., 2018).

\section{Lebar pantai}

Pengukuran lebar pantai pada setiap titik sampling dilakukan dengan menggunakan roll meter, yaitu diukur jarak antara vegetasi terakhir yang ada di pantai dengan batas pasang tertinggi (Kamah et al., 2013).

\section{Material Dasar Perairan}

Pengamatan pada material dasar perairan atau substrat dengan cara didasarkan pada hasil pengamatan jenis susbtrat dengan melihat karakteristik butir sedimennya. Analisis sampel substrat dilakukan dengan metode pengayakan kering (dry sieving) yang selanjutnya diklasifikasikan menggunakan Gradistat software. P rosedur metode pengamatannya yaitu, pengambilan substrat pada masing-masing titik sampling sebanyak 250 gram dan dimasukan ke dalam plastik sampel yang kemudian diberi label, sampel dibersihkan dari kotoran yang menempel, kemudian sampel substrat dikeringkang dan dibungkus menggunakan aluminium foil dan dimasukkan ke dalam oven dengan suhu 100 105 o selama 24 jam. Kemudian menimbang sampel yang telah kering untuk masing-masing titik sampling seberat 100 gram sebagai berat awal, mengayak sampel yang telah ditimbang dengan menggunkan sieve net yang tersusun secara berurutan dengan ukuran (mesh size) 4 mm, 2 mm, 1 mm, $500 \mu \mathrm{m}, 212 \mu \mathrm{m}, 106 \mu \mathrm{m}$, dan < $106 \mu \mathrm{m}$. Mengayak dengan menggerakkan sieve net secara konstan sekitar 10 menit, sehingga didapatkan pemisah ukuran masing-masing partikel sedimen berdasarkan ukuran ayakan. Selanjutnya, memisakan sampel dari ayakan (untuk antisipasi tertinggalnya butiran pada ayakan, sieve net disikat dengan sikat bulu secara perlahan) kemudian masing-masing partikel sedimen ditimbang berdasarkan ukurannya menggunakan neraca analitik dengan wadah cawan petri. Selanjutnya dilakukan analisis besar butiran sedimen dilakukan dengan perhitungan. Untuk menghitung persen (\%) berat sedimen pada metode yakan kering dapat digunakan rumus sebagai berikut:

$$
\% \text { Berat }=\frac{\text { Berat kering setiap ayakan }}{\text { Berat total seluruh ayakan }} \times 100 \%
$$

Setelah dilakukan perhitungan berat sedimen yang telah dikeringkan, disesuaikan dengan jenis besar butir berdasarkan klasifikasi Gradistat.

\section{Kecepatan Arus}

Kecepatan arus diukur menggunakan current drogue, yakni dengan menetapkan jarak tempuh current drogue (2 meter) kemudian diukur waktu tempuh current drogue tersebut. Perhitungan kecepatan arus menggunakan rumus:

$$
v=\frac{s}{t}
$$

Ketereangan: V merupakan kecepatan Arus, s merupakan panjang lintasan parasut arus (m), t merupakan waktu tempuh layang-layang arus (detik).

\section{Kemiringan Pantai}

Pengukuran kemiringan pantai dapat diketahui dengan melihat kedalaman pantai maka akan diketahui sudut kemiringan pantai. Pengukuran kemiringan pantai dilakukan menggunakan roll meter dan tongkat berukuran 2 meter. Langkah pertama, kayu berukuran 2 meter diletakkan secara horizontal di atas pasir dan dilekatkan tepat pada batas pantai teratas. Setelah dipastikan horizontal, dihitung ketinggian tongkat tersebut dengan rollmeter. Sehingga dapat diketahui kemiringan pantai tersebut dengan cara menghitung sudut yang dibentuk antara garis horizontal dan vertikal yang didapatkan (Lestari, 2013). Pengukuran ini dilakukan dari batas pantai teratas dap at dilihat pada Gambar 2. 


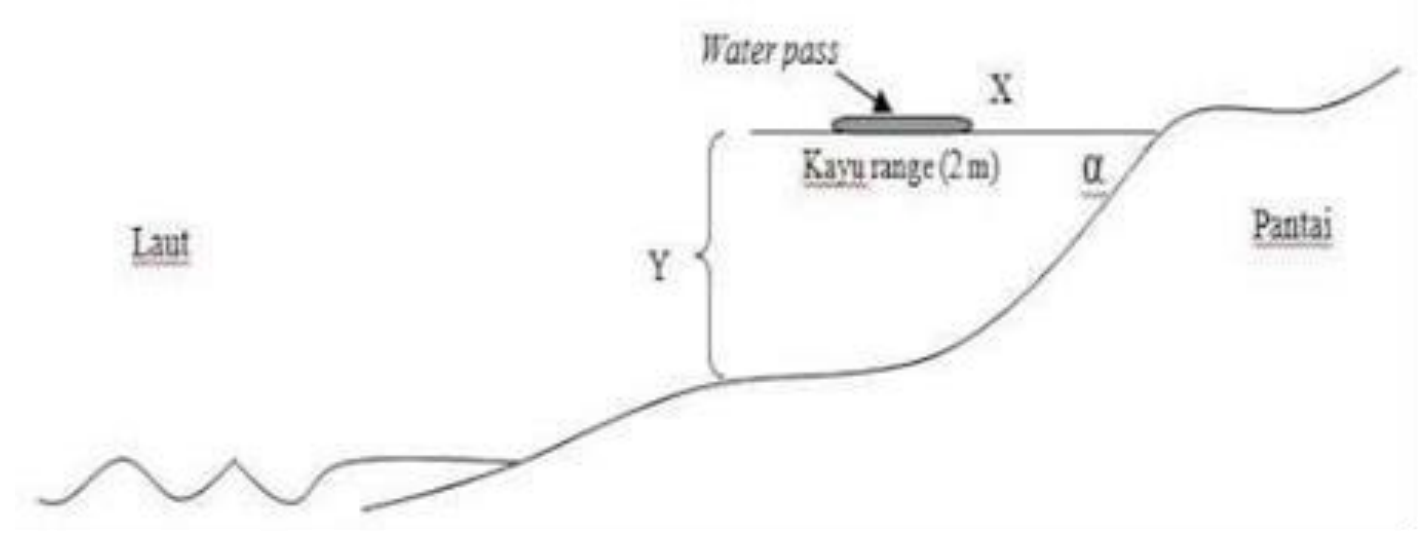

Gambar 3. Pengukuran kemiringan pantai

Kemudian akan didapatkan sudut kemiringan pantai tersebut dengan menggunakan rumus Lestari (2013):

$$
\frac{Y}{X}
$$

Keterangan: $\alpha$ merupakan udut yang dibentuk (0), X merupakan jarak antara garis tegak lurus yang dibentuk secara horizontal dengan permukaan pasir bawahnya (m), Y merupakan kedalaman (m).

\section{Kecerahan Pantai}

Pengukuran kecerahan dilakukan dengan menggunakan secchi disk yang diikat dengan tali kemudian diturunkan perlahan-lahan ke dalam perairan pada lokasi pengamatan sampai pada batas visual secchi disk tersebut tidak dapat terlihat lalu mengukur panjang tali dan mencatat posisi pengambilan data. Perhitungan dilakukan menggunakan rumus:

$$
\text { Kecerahan air }(m)=\frac{D 1+D 2}{2}
$$

Keterangan: D1 merupakan jarak tidak tamnpak (m), D2 merupaka jarak tampak (m).

\section{Biota Berbahaya}

Pengamatan biota berbahaya dilakukan dengan wawancara kepada m asyarakat sekitar sebagai responden. Bulu babi dan ikan pari menjadi indikator biota berbahaya karena kedua biota laut ini memiliki d uri yang berbahaya bagi manusia (Juliana, 2013). Selain bulu babi dan ikan pari, ikan lepu dan hiu juga termasuk ke dalam b iota berbahaya.

\section{Aksesibilitas}

Dalam menentukan kelas kemampuan aksesibilitas kawasan wisata, maka peneliti melakukan pengambilan data menggunakan metode visual dengan bagaimana aksesibilitas menuju kawasan wisata pantai. Dalam penelitian ini aksesibilitas dilihat dari 3 ketentuan antara lain, adanya akses jalan yang mudah dilalui, adanya sarana transportasi umum dan adanya rambu-rambu penunjuk jalan.

\section{Sarana dan Prasarana}

Sarana dan prasarana yang diukur dalam penelitian ini dilihat dari 3 ketentuan dimana dapat menunjang aktivitas pengunjung saat berwisata ke Pantai tersebut. Penilaian kawasan pantai yang akan dijadikan kawasan wisata dilihat dari akomodasi, tempat makan dan minum dan fasilitas umum.

\section{Penutupan Lahan Pantai}

Penutupan lahan pantai dilakukan berdasarkan pengamatan visual di lapangan, (Kamah et al., 2013). Penentuan penutupan lahan dilakukan dengan mengamati daerah sekitar pantai pada 3 titik sampling, kemudian menggolongkan apakah masing-masing titik sampling tergolong dalam lahan terbuka dengan pohon kelapa, savana, semak belukar rendah, semak berlukar tinggi, permukiman atau pelabuhan (Chasanah et al., 2017). Selanjutnya, setiap jenis vegetasi pada penutupan lahan pantai dimasukkan ke dalam plastik sampel untuk diidentifikasi. Ident ifikasi jenis tumbuhan pantai Menggunakan Buku Panduan Pengenalan Mangrove Di Indonesia (Noor et al., 2006).

\section{Ketersediaan Air Tawar}

Pengamatan ketersediaan air tawar dilakukan dengan cara mengukur jarak antara titik sampling penelitian dengan lokasi dimana sumber air tawar tersedia (Kamah et al., 2013). 


\subsection{Teknik Pengumpulan Data}

Dalam penelitian ini data yang dikumpulkan yaitu data primer dan data sekunder. Data primer merupakan data hasil pengukuran parameter potensi ekologi dan data hasil wawancara potensi sosial serta dokumentasi kawasan perairan pantai. Data potensi ekologi yaitu, kedalaman, tipe pantai, lebar pantai, material dasar perairan, kecepatan arus, kemiringan pantai, kecerahan pantai, penutupan lahan pantai, biota berbahaya, ketersediaan air tawar, aksesibilitas serta sarana dan prasarana. Data potensi sosial yaitu persepsi masyarakat dan partisipasi masyarakat. Data sekunder merupakan data yang diperoleh dari literatur pendukung berupa data pustaka, penelitian terdahulu, jurnal serta sumber aktual lainnya. Data sekunder dalam penelitian ini terdiri dari kondisi umum wilayah, kondisi geografis dan kondisi demografi.

\subsection{Analisis Data}

Analisis yang digunakan dalam penelitian ini adalah analisis deskriptif. Analisis deskriptif digunakan untuk melihat dan menyajikan informasi dan data dari penelitian dalam bentuk gambar, grafik dan tabel baik dari hasil observasi, wawancara, kuesioner maupun data sekunder lainnya.

\subsubsection{Analisis Data Potensi Ekologi}

Data yang diperoleh dianalisis secara deskriptif kuantitatif. Analisis data yang digunakan dalam penelitian ini adalah analisis kesesuaian kawasan wisata pantai mencakup penyusunan matriks kesesuaian, pembobotan dan peringkat, serta analisis indeks kesesuaian setiap kategori wisata pantai. Selanjutnya penentuan indeks kesesuaian untuk wisata pantai menggunakan rumus:

$$
\mathrm{IKW}=\frac{\mathrm{Ni}}{\sum \mathrm{Nmax}} \times 100 \%
$$

Keterangan:

IKW = Indeks Kesesuaian Wisata,

$\mathrm{Ni} \quad=$ Nilai parameter ke-i (bobot $\times$ skor $)$,

Nmaks = Nilai maksimum dari suatu kategori wisata.

Pemberian bobot setiap aspek berdasarkan tingkat kepentingan dalam suatu variabel dan pemberian skor berdasarkan kualitas parameter kesesuaian selama proses pengambilan data di lapangan (Tabel 1). Matriks kesesuaian kawasan wisata pantai dan indeks kesesuaian wisata dapat dilihat pada Tabel 2 dan Tabel 3.

Tabel 1. Pemberian bobot dan skor kesesuaian wisata pantai

\begin{tabular}{lcl} 
No & Pemberian & \\
1 & Bobot 5 & Didasarkan pada pemikiran bahwa parameter ini sangat diperlukan atau parameter kunci \\
2 & Bobot 3 & $\begin{array}{l}\text { Didasarkan pada pemikiran bahwa parameter ini diperlukan } \\
\text { Didasarkan pada pemikiran bahwa parameter ini dalam penelitian tidak begitu diperlukan } \\
\text { parameter kurang penting, yang artinya tanpa adanya parameter ini kegiatan wisata masih } \\
\text { berjalan. }\end{array}$ \\
& Bobot 1 & Kondisi parameter yang sangat baik \\
4 & Skor 3 & Kondisi parameter memiliki kualitas cukup baik \\
5 & Skor 2 & Kondisi parameter memiliki kualitas baik bersyarat \\
6 & Skor 1 & Kondisi parameter memiliki kualitas yang buruk \\
\hline
\end{tabular}

Sumber: Modifikasi Yulianda (2007)

Menentukan indeks kesesuaian wisata digunakan perhitungan yang didasarkan pada selisih total nilai maksimum dan minimum serta rentang skor. Rentang skor yang digunakan untuk menentukan tingkat kesesuaian wisata diacu pada formula yang digunakan Yusuf (2007), yaitu:

$$
\text { Rentang Skor }=\frac{\text { Total skor tertinggi }- \text { Total skor terendah }}{\text { Jumlah Kelas }}
$$

Hasil perhitungan yang diperoleh dari jumlah perkalian antara bobot dan skor yang disesuaikan dengan kategori klasifikasi. Kriteria kesesuaian kawasan tersebut dikelompokkan kedalam 4 (empat) kategori yaitu Sl (sangat sesuai), S2 (cukup sesuai), S3 (sesuai bersyarat) dan N (tidak sesuai). Berdasarkan pada nilai indeks kesesuaian lahan untuk wisata pantai pada tabel 2 diatas didapatkan perhitungan dengan skor tertinggi ll4 dan terendah 4 dengan rentang skor 28,5. Dengan demikian dapat diperoleh kelas-kelas kesesuaian wisata sebagai berikut:

$\mathrm{Sl}$ (sangat sesuai) $\quad=71,5-100 \%$

S2 (cukup sesuai) $\quad=43-71,5 \%$

S3 (sesuai bersyarat) $\quad=14,5-43 \%$

$\mathrm{N}$ (tidak sesuai) $\quad=<14,5 \%$ 
Tabel 2. Matriks Kesesuaian Kawasan Wisata Pantai

\begin{tabular}{|c|c|c|c|c|c|c|c|c|c|c|}
\hline No & Parameter & Bobot & Kategori S1 & Skor & $\begin{array}{c}\text { Kategori } \\
\text { S2 }\end{array}$ & Skor & Kategori S3 & Skor & \multicolumn{2}{|c|}{$\begin{array}{l}\text { Kategori N } \\
\text { Skor }\end{array}$} \\
\hline 1 & $\begin{array}{l}\text { Kedalaman } \\
\text { perairan (m) }\end{array}$ & 5 & $0-3$ & 3 & $>3-6$ & 2 & $>6-10$ & 1 & $>10$ & 0 \\
\hline 2 & Tipe pantai & 5 & pasir putih & 3 & $\begin{array}{l}\text { pasir } \\
\text { putih, } \\
\text { sedikit } \\
\text { karang }\end{array}$ & 2 & $\begin{array}{l}\text { Pasir } \\
\text { Hitam, } \\
\text { berkarang, } \\
\text { sedikit } \\
\text { terjal }\end{array}$ & 1 & $\begin{array}{l}\text { lumpur, } \\
\text { berbatu, } \\
\text { terjal }\end{array}$ & 0 \\
\hline 3 & $\begin{array}{l}\text { Lebar pantai } \\
(\mathrm{m})\end{array}$ & 5 & $>15$ & 3 & $10-15$ & 2 & $3-<10$ & 1 & $<3$ & 0 \\
\hline 4 & $\begin{array}{l}\text { Material } \\
\text { dasar } \\
\text { perairan }\end{array}$ & 3 & pasir & 3 & $\begin{array}{l}\text { karang } \\
\text { berpasir }\end{array}$ & 2 & $\begin{array}{l}\text { pasir ber- } \\
\text { lumpur }\end{array}$ & 1 & lumpur & 0 \\
\hline 5 & $\begin{array}{l}\text { Kecepatan } \\
\operatorname{arus}(\mathrm{m} / \mathrm{dt})\end{array}$ & 3 & $0-0,17$ & 3 & $0,17-0,34$ & 2 & $0,34-0,51$ & 1 & $>0,51$ & 0 \\
\hline 6 & $\begin{array}{l}\text { Kemiringan } \\
\text { pantai }\left(^{\circ}\right)\end{array}$ & 3 & $<10$ & 3 & $10-25$ & 2 & $>25-45$ & 1 & $>45$ & 0 \\
\hline 7 & $\begin{array}{l}\text { Kecerahan } \\
\text { Perairan }(\%)\end{array}$ & 3 & $>80$ & 3 & $50-80$ & 2 & $20-<50$ & 1 & $\begin{array}{l}<20 \\
\text { (terdapat } \\
\text { sampah - } \\
\text { kekeruhan } \\
\text { tinggi) }\end{array}$ & 0 \\
\hline 8 & $\begin{array}{l}\text { Biota } \\
\text { berbahaya } \\
\text { (modifikasi) }\end{array}$ & 3 & $\begin{array}{l}\text { tidak } \\
\text { ada }\end{array}$ & 3 & $\begin{array}{l}\text { bulu babi } \\
/ \\
\text { spesies }\end{array}$ & 2 & $\begin{array}{l}\text { bulu babi, } \\
\text { ikan pari / } \\
2 \text { spesies }\end{array}$ & 1 & $\begin{array}{l}\text { bulu babi, } \\
\text { ikan pari, } \\
\text { lepu, hiu / } \\
\text { >2 spesies }\end{array}$ & 0 \\
\hline 9 & $\begin{array}{l}\text { Aksesibilitas } \\
\text { (modifikasi) }\end{array}$ & 3 & $\begin{array}{l}3 \\
\text { ketentuan }\end{array}$ & 3 & $\begin{array}{l}2 \\
\text { ketentuan }\end{array}$ & 2 & $\begin{array}{l}1 \\
\text { ketentuan }\end{array}$ & 1 & Tidak ada & 0 \\
\hline 10 & $\begin{array}{l}\text { Sarana dan } \\
\text { prasarana } \\
\text { (modifikasi) }\end{array}$ & 3 & $\begin{array}{l}3 \\
\text { ketentuan }\end{array}$ & 3 & $\begin{array}{l}2 \\
\text { ketentuan }\end{array}$ & 2 & $\begin{array}{l}1 \\
\text { ketentuan }\end{array}$ & 1 & Tidak ada & 0 \\
\hline 11 & $\begin{array}{l}\text { Penutupan } \\
\text { lahan pantai }\end{array}$ & 1 & $\begin{array}{l}\text { kelapa, } \\
\text { lahan } \\
\text { terbuka }\end{array}$ & 3 & $\begin{array}{l}\text { semak } \\
\text { belukar, } \\
\text { rendah, } \\
\text { savana }\end{array}$ & 2 & $\begin{array}{l}\text { belukar } \\
\text { tinggi }\end{array}$ & 1 & $\begin{array}{l}\text { hutan } \\
\text { bakau, } \\
\text { pemukiman } \\
\text {, pelabuhan }\end{array}$ & 0 \\
\hline 12 & $\begin{array}{l}\text { Ketersediaan } \\
\text { air tawar } \\
(\mathrm{km})\end{array}$ & 1 & $<0,5(\mathrm{~km})$ & 3 & $\begin{array}{l}>0,5-1 \\
(\mathrm{~km})\end{array}$ & 2 & $>1-2$ & 1 & $>2$ & 0 \\
\hline
\end{tabular}

Sumber: Modifikasi Yulianda (2007)

Tabel 3. Kelas Indeks Kesesuaian Wisata

No Kelas Kesesuaian

1 S1 (sangat sesuai) 71,5-100\%

2 S2 (cukup sesuai) $43-71,5 \%$

3 S3 (sesuai bersyarat) $14,5-43 \%$

$4 \quad \mathrm{~N}$ (tidak sesuai) $<14,5 \%$

\section{Keterangan}

Kawasan ekosistem pantai yang sangat sesuai untuk dimanfaatkan sebagai kawasan wisata pantai, tidak mempunyai faktor pembatas yang berat atau hanya mempunyai faktor pembatas yang kurang berarti terhadap kondisi kawasan dan tidak terlalu memerlukan masukan untuk pengembangannya sebagai objek kawasan wisata pantai.

Kawasan ekosistem pantai yang cukup sesuai untuk dimanfaatkan sebagai kawasan wisata pantai. Faktor pembatas yang agak berat untuk suatu penggunaan kegiatan tertentu secara lestari. Faktor pembatas tersebut akan mempengaruhi kepuasan dalam kegiatan wisata sehingga diperlukan upaya tertentu dalam pengelolaan ekosistem pantai tersebut.

Kawasan ekosistem pantai yang sesuai namun bersyarat untuk dimanfaatkan sebagai kawasan wisata pantai. Kategori ini memiliki faktor pembatas yang lebih banyak untuk dipenuhi. Faktor pembatas tersebut akan mengurangi kepuasan sehingga untuk melakukan kegiatan wisata faktor pembatas tersebut harus lebih diperhatikan sehingga ekosistem dapat dipertahankan.

Kawasan ekosistem pantai yang mengalami kerusakan yang tinggi atau tidak memiliki keunggulan fisik kawasan sehingga tidak memungkinkan untuk dikembangkan sebagai kawasan wisata pantai. Sangat disarankan untuk dilakukan perbaikan atau pengelolaan secara berkelanjutan. 


\subsubsection{Analaisis Data Daya Dukung Kawasan}

Daya dukung kawasan adalah jumlah maskimum pengunjung yang secara fisik dapat ditampung oleh kawasan yang disediakan pada waktu tertentu tanpa menimbulkan gangguan pada alam dan manusia. Secara matematis dapat diformulasikan sebagai berikut (Yulianda et al., 2010):

$$
\mathrm{DDK}=\mathrm{K} \times \frac{\mathrm{Lp} \times \mathrm{Wt}}{\mathrm{Lt} \times \mathrm{Wp}}
$$

Keterangan: DDK merupakan daya dukung kawasan, K merupakan potensi ekologi pengunjung per satuan unit area (jiwa), Lp merupakan luas area panjang area yang dapat dimanfaatkan, Lt merupakan unit area untuk kategori tertentu, Wt merupakan waktu yang disediakan oleh kawasan untuk kegiatan wisata dalam satu hari, Wp merupakan waktu yang dihabiskan oleh pengunjung untuk setiap kegiatan.

Tabel 4. Potensi ekologis pengunjung $(\mathrm{K})$ dan luas area kegiatan (Lt) dan prediksi waktu yang dibutuhkan untuk setiap kegiatan wisata.

\begin{tabular}{cccccc} 
No & Jenis Kegiatan & $\begin{array}{c}\text { Pengunjung } \\
\text { (K) }\end{array}$ & Unit Area (Lt) & $\begin{array}{c}\text { Waktu yang } \\
\text { Dibutuhkan(Wp) }\end{array}$ & $\begin{array}{c}\text { Total Waktu Satu } \\
\text { (Wt) Hari }\end{array}$ \\
\hline 1 & Wisata Pantai & 1 Jiwa & $50 \mathrm{~m}^{2}$ & 3 & 6 \\
\hline & Sumber: Yulianda et al. $(2010)$ & &
\end{tabular}

Keterangan: Wisata pantai merupakan 1 orang setiap $50 \mathrm{~m}^{2}$ panjang pantai.

\section{HASIL DAN PEMBAHASAN}

\subsection{Kondisi Umum Wilayah}

Pulau Terkulai adalah pulau kecil yang terletak di Kelurahan Senggarang, Kecamatan Tanjunginang Kota, Kota Tanjungpinang, Provinsi Kepulauan Riau. Pulau Terkulai berada di titik koordinat 057’9.249 LU 104²0'23.281” BT. Secara geografis wilayah Pulau Terkulai berbatasan dengan:

Sebelah Utara : : Desa Busung

Sebelah Selatan : : Pulau Sembulang

Sebelah Barat $\quad$ : Pulau Anak Lobam

Sebelah Timur : : Kelurahan Senggarang

Pulau Terkulai merupakan pulau terluar Kota Tanjungpinang yang berada pada jalur pelayaran kapal sehingga menjadi lokasi distrik navigasi kelas 1 Tanjungpinang yang terdapat menara suar di bawah pengelolaan Kementerian Perhubungan Direktorat Jendral Perhubungan Laut. Pulau Terkulai memiliki potensi sumberdaya alam dengan keindahan pantai pasir putih sepanjang \pm 2 kilometer yang ditumbuhi pohon kelapa, cemara laut dan savana menjadikan pantai ini terlihat lebih indah dan sejuk serta birunya warna laut menjadi salah satu daya tarik dari pantai ini (Gambar 2).Berdasarkan hasil pengamatan, garis pantai yang terbentang panjang memberikan ruang kepada wisatawan untuk dapat melakukan berbagai aktivitas wisata. Kedalaman perairan yang dangkal serta arus gelombang yang kecil di sekitar pantai Pulau Terkulai memungkinkan aktivitas wisata dapat berjalan dengan baik. Potensi sumberdaya alam yang masih alami dan iklim tropis yang cocok untuk berwisata yang terdapat di Pantai Terkulai memberikan atraksi wisata dan menjadi faktor pendukung bagi pengembangan kawasan wisata di pantai Pulau Terkulai ini.

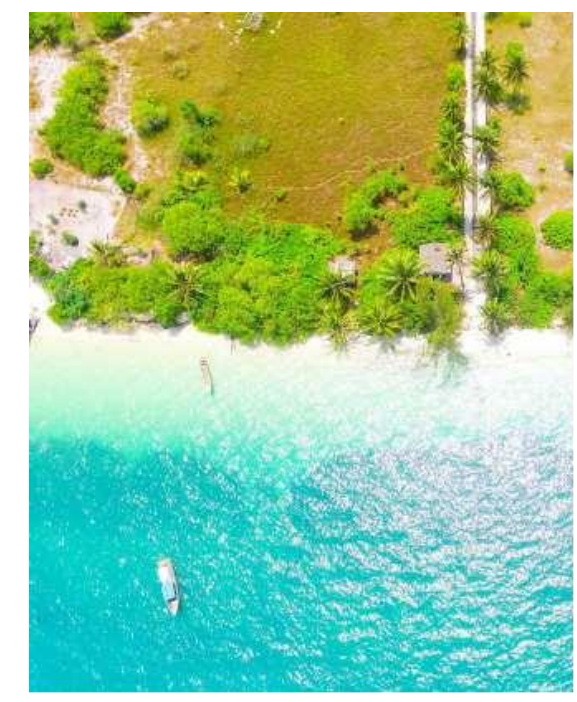

Gambar 2. Kondisi Pantai Pulau Terkulai 


\subsection{Potensi Ekologi}

\subsubsection{Kedalaman Pulau Terkulai}

Karakteristik kedalaman perairan merupakan faktor yang sangat penting untuk kenyamanan dan keamanan pengunjung yang melakukan kegiatan wisata pantai terutama mandi dan berenang. Berdasarkan pengukuran kedalaman perairan Pulau Terkulai diketahui bahwa pantai Pulau Terkulai merupakan perairan yang relatif dangkal dengan kedalaman pada titik sampling I, II dan III memiliki nilai tidak lebih besar dari 3 meter. Kesesuaian kedalaman perairan yang merupakan salah satu parameter kunci ini terkat egori Sl atau sangat sesuai dan mendapatkan skor 3 dengan kondisi parameter yang sangat baik sebagai kawasan wisata pantai. Hal ini menunjukkan, perairan Pulau Terkulai merupakan kawasan yang sangat sesuai untuk melakukan kegiatan rekreasi pantai karena para pengunjung dapat beraktivitas dengan aman dan nyaman. Kedalaman yang sangat sesuai tersebut didukung oleh pernyataan Habibi et al. (2017), sebagai kawasan wisata pantai khususnya mandi dan renang kedalaman perairan sangat berpengaruh pada aspek keselamatan dan kenyamanan pada saat berenang, dimana kedalaman relatif dangkal lebih baik untuk objek wisata mandi dan berenang.

\subsubsection{Tipe Pantai Pulau Terkulai}

Hasil pengamatan tipe pantai di Pulau Terkulai pada titik sampling pengamatan parameter menunjukkan bahwa pada titik sampling I memiliki pasir putih yang masuk dalam kategori Sl atau sangat sesuai, pada titik sampling II memiliki pasir putih sedikit karang dalam kategori S2 atau cukup sesuai dan pada titik sampling III memiliki pasir putih masuk dalam kategori Sl atau sangat sesuai (Gambar 3). Tipe pantai di Pulau Terkulai tersebut mendapat skor 3 pada titik sampling I dan III yaitu kondisi parameter dengan kualitas sangat baik dan pada titik sampling II yaitu kondisi parameter dengan kualitas cukup baik sebagai kawasan wisata pantai. Pantai yang memiliki tekstur pasir pantai yang halus menjadi salah satu faktor penting dalam berwisata rekreasi pantai jika dibandingkan pantai berbatu dan berkarang (Chasanah et al., 2017). Salah satu variabel yang membuat pengunjung ingin berwisata ke Pulau Terkulai adalah tipe pantainya karena memiliki tipe pantai pasir putih yang mempunyai nilai tersendiri bagi estetika pantai karena tipe pantai seperti ini sangat diminati oleh pengunjung.

Pada pengamatan titik sampling II memiliki tipe pantai pasir putih dengan sedikit pecahan karang yang terbawa oleh arus. Kondisi tipe pantai pada titik sampling II akan mempengaruhi kepuasan pengunjung terhadap kenyamanan dan keamanan pengunjung. Hamparan pantai dengan pasir putih pada titik sampling I dan III merupakan daya tarik yang diminati oleh pengunjung untuk melakukan kegiatan berjemur maupun kegiatan lainnya di pantai. Faktor lainnya yaitu pasir yang berwarna putih tidak mudah menyerap sinar matahari sehingga tidak menyebabkan panas di kaki yang akan mempengaruhi kenyamanan pada pengunjung (Febyanto et al., 2014).

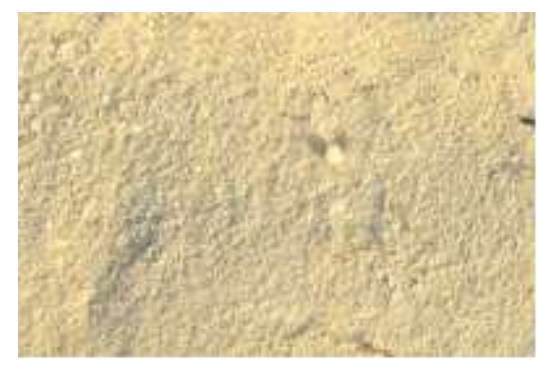

Titik sampling I Pasir putih

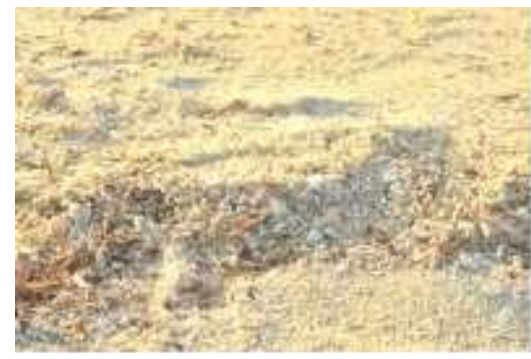

Titik sampling II Pasir putih, sedikit karang

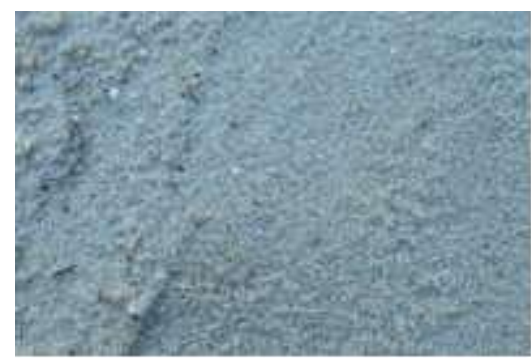

Titik sampling 3 Pasir putih

Gambar 3. Tipe Pantai Pulau Terkulai

\subsubsection{Lebar Pantai Pulau Terkulai}

Lebar pantai sangat mempengaruhi aktivitas yang dilakukan para pengunjung, semakin lebar suatu pantai maka semakin baik bagi pengunjung melakukan aktivitasnya. Namun, semakin kecil lebar pantai yang dimiliki oleh suatu tempat wisata maka pengunjung merasa tidak nyaman untuk melakukan aktivitas. Pengukuran lebar pantai Pulau Terkulai pada Tabel 16 menunjukkan bahwa pengukuran pada titik sampling I, yaitu 6,09 meter, masuk dalam kategori sesuai bersyarat (S3). Pada titik sampling II, lebar pantai cukup sesuai (S2) dengan lebar sepanjang 11,69 meter. Lebar pantai pada titik sampling III masuk dalam kategori sesuai bersyarat (S3) yaitu sepanjang 7,02 meter.

Lebar pantai Pulau Terkulai masih sesuai untuk melakukan aktivitas pantai yang memiliki lebar >6 meter karena pantainya yang cukup lebar sehingga masih dapat menampung pengunjung dalam beraktivitas, walaupun faktor pembatas tersebut dapat mengurangi kepuasan pengunjung yang tidak dapat leluasa dalam melakukan aktivitas wisata pantai. Hal ini didukung oleh penelitian Lalloltery et al. (2016), yang menyatakan bahwa ukuran lebar pantai ini masih memungkinkan wisatawan dapat melakukan berbagai aktivitas wisata seperti bermain pasir, menikmati pemandangan pantai dan laut, berfoto dan bermain di tepi pantai. 


\subsubsection{Material Dasar Perairan Pulau Terkulai}

Jenis material dasar perairan yang dimiliki oleh Pulau Terkulai dari ketiga titik sampling adalah jenis pasir sangat kasar (very coarse sand) dengan kategori pasir (Gambar 4). Persentase fraksi menunjukkan tid ak adanya substrat lumpur pada perairan Pulau Terkulai pada 3 titik sampling tersebut. Rata-rata persentase fraksi material dasar perairan Pulau Terkulai yaitu kerikil 18,7\% dan didominansi pasir 81,3\%. Persentase substrat pasir mendominansi pada perairan Pulau Terkulai dibandingkan dengan kerikil. Pada titik sampling II persentase fraksi kerikil lebih besar dibandingkan dengan titik sampling I dan III, dikarenakan pada titik sampling II memiliki jenis tipe pantai pasir putih sedikit karang.

Jenis material dasar perairan Pulau Terkulai disimpulkan bahwa terkategori Sl atau sangat sesuai untuk melakukan aktivitas wisata pantai. Kategori yang sangat sesuai untuk melakukan wisata pantai adalah pasir yang dapat memberikan kenyamanan dan keamanan bagi pengunjung untuk melakukan aktivitas wisata pantai. Berdasarkan hasil kesesuaian tersebut, menurut Subandi (2018), secara umum material dasar perairan tipe pasir masih baik dan mendukung kegiatan wisata pantai seperti berenang dan rekreasi.

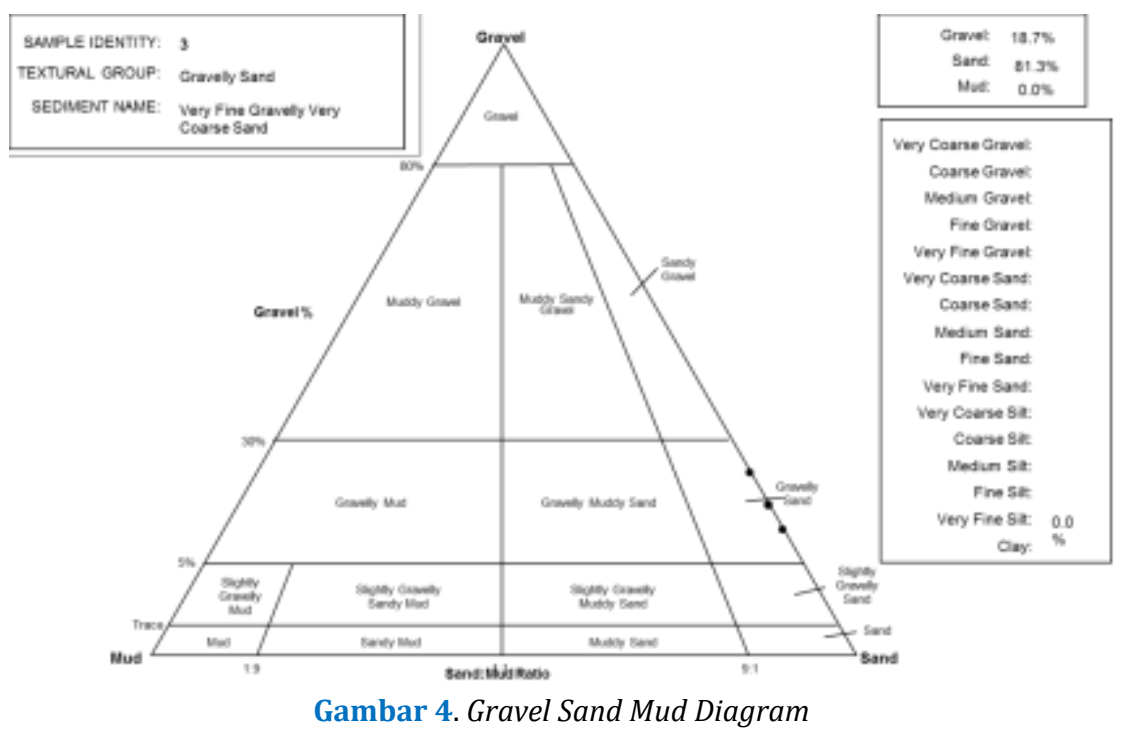

Pada diagram di atas, menginformasikan bahwa dengan rata-rata nilai persen kerikil (gravel) yaitu 18,7\% dan pasir (sand) sebesar 81,3\% pada ketiga titik sampling termasuk ke dalam tekstur kelompok gravelly sand atau pasir berkerikil dengan nama sedimen very fine gravelly atau very coarse sand. Jumlah persen gravel ditandai dengan 3 titik hitam pada diagram tersebut.

\subsubsection{Kecepatan Arus Pulau Terkulai}

Berdasarkan hasil pengukuran kecepatan arus di perairan pantai Pulau Terkulai pada saat air pasang menuju surut menunjukkan pola arus permukaan mempunyai kecepatan berkisar antara 0,06-0,09 m/dtk pada titik sampling I, II dan III, dimana kecepatan arus tersebut tergolong arus yang lambat dan termasuk kategori Sl atau sangat sesuai untuk aktivitas wisata pantai. Hal ini sesuai dengan pernyataan Yulianda (2007), bahwa kecepatan arus sangat sesuai untuk kegiatan wisata pantai yaitu 0-0,17 m/dtk.

Kecepatan arus di Pulau Terkulai pada 3 titik sampling yang terkategori lambat tersebut, karena merupaka n daerah yang terlindung dan diapit oleh pulau-pulau di sekitarnya. Hal ini sesuai dengan pernyataan Karnanda et al. (2019), bahwa pantai yang terlindung dari hembusan angin yang terhalang oleh keberadaan pulau lain yang mempengaruhi arus sesuai untuk mandi dan berenang di laut. Waktu pengukuran yaitu saat pasang menuju surut dan saat musim angin selatan yang mempengaruhi kecepatan arus. Kondisi kecepatan arus yang lambat akan memberikan rasa nyaman kepada pengunjung saat melakukan aktivitas renang, karena pengunjung tidak akan terbawa oleh arus yang dapat membahayakan pengunjung. Habibi et al. (2017), juga menyatakan hal yang sama bahwa arus yang lambat dan tenang memberikan rasa nyaman untuk aktivitas mandi dan renang serta aktivitas wisata pantai lainnya.

\subsubsection{Kemiringan Pantai Pulau Terkulai}

Kemiringan pantai pada suatu kawasan wisata cenderung mempengaruhi keamanan seseorang untuk melakukan kegiatan wisata pantai seperti bermain pasir dan bermain-main dengan ombak di tepian pantai. Kemiringan pantai Pulau Terkulai pada ketiga titik sampling pengukuran parameter yaitu <10o. Berdasarkan hasil pengukuran tersebut dapat disimpulkan kemiringan pantai Pulau Terkulai tergolong datar dan termasuk kategori Sl atau sangat sesuai untuk aktivitas wisata pantai dengan kondisi parameter yang sangat baik yaitu skor 3 . Kemiringan pantai $\leq 10 \mathrm{o}$ dianggap sangat sesuai untuk wisata pantai, sedangkan kemiringan pantai yang >45 o dianggap tidak sesuai untuk wisata pantai karena terkategori terjal yang dapat membahayakan pengunjung dalam beraktivitas berenang maupun 
aktivitas lainnya. Subandi et al. (2018), juga menyatakan pantai datar sampai landai sangat baik untuk kegiatan wisata renang dimana wisatawan dapat melakukan berbagai kegiatan seperti berenang, bermain pasir serta da pat bermainmain dengan ombak di tepinya.

\subsubsection{Kecerahan Pantai Pulau Terkulai}

Kecerahan perairan di Pulau Terkulai pada titik sampling I, II dan III yaitu 100\%, dimana nilai kecerahan sama dengan nilai kedalaman perairan. Kecerahan perairan dipengaruhi oleh kemiringan pantai yang datar sehingga pada kedalaman tersebut kecerahan tampak hingga dasar perairannya dan kecerahan juga dipengaruhi oleh keadaan cuaca yang cerah saat pengukuran. Kondisi perairan dengan kecerahan yang tinggi didukung ol eh letak Pulau Terkulai di tengah-tengah laut sehingga tidak ada pengaruh air sungai, limbah aktivitas manusia maupun bahan-bahan anorganik yang tersuspensi sehingga dasar perairan masih tampak dengan pengamatan visual.

Berdasarkan hasil pengukuran tersebur dapat disimpulkan bahwa kecerahan perairan Pulau Terkulai pada ketiga titik sampling termasuk kategori Sl atau sangat sesuai untuk melakukan aktivitas wisata pantai dengan nilai $>80 \%$ dengan kondisi parameter yang sangat baik. Tingginya kecerahan perairan Pulau Terkulai memiliki keindahan air laut yang memancarkan kejernihan dan membuat pengunjung ingin sekali untuk berwisata pantai di Pulau tersebut. Sama halnya menurut Chasanah et al. (2017), bahwa selain menjadi parameter kualitas air, kecerahan juga menjadi parameter dalam kesesuaian wisata yaitu untuk menjadi parameter yang mencirikan nilai keindahan pemandangan saat melakukan kegiatan berwisata.

\subsubsection{Identifikasi Biota Berbahya Pulau Terkulai}

Berdasarkan hasil wawancara dengan masyarakat nelayan dan pengunjung bahwa di Pulau Terkulai terdapat bulu babi jenis Echinometra viridis, ikan lepu dan ikan pari pada sisi selatan Pulau Terkulai yang terdapat di ekosistem karang dan merupakan area penangkapan (fishing ground) bagi nelayan. Namun, pada lokasi penelitian titik sampling I dan II tidak terdapat biota berbahaya, seperti bulu babi, ikan lepu, ikan pari, dan lain sebagainya. Kondisi seperti ini dikategorikan sangat sesuai (Sl) untuk kegiatan wisata pantai karena memberikan kenyamanan dan keamanan bag i pengunjung yang melakukan aktivitas di kawasan wisata pantai yang memiliki rasa takut dan khawatir apabila melakukan aktivitas seperti renang. Berdasarkan pernyataan Yulianda (2007), bahwa kawasan yang tidak memiliki biota berbahaya merupakan kawasan yang sangat sesuai untuk objek rekreasi mandi dan berenang. Menurut Subandi et al. (2018), tidak ditemukannya bulu babi karena tidak ditemukannya vegetasi lamun yang dimanfaatkan bulu babi (Diadema sp) sebagai habitat dan sebagai makanan utamanya. Ikan lepu juga tidak ditemukan karena pada titik sampling pengamatan memiliki jarak yang jauh terhadap terumbu karang.

Pada titik sampling III terdapat biota berbahaya bulu babi jenis Echinometra viridis dan kerang kampak jenis Atrina pectinate pada daerah yang berbatu dan sedikit karang. Kondisi ini terkategori sesuai bersyarat (S2) dimana adanya faktor pembatas yang mengurangi kepuasan pengunjung karena dapat membahayakan pengunjung saat beraktivitas di pantai. Pengunjung harus lebih berhati-hati jika beraktivitas pada titik sampling III karena bulu babi menjadi indikator biota berbahaya dimana spesies biota laut ini memiliki duri yang berbahaya bagi manusia (Juliana, 2013).

\subsubsection{Aksesibilitas Pulau Terkulai}

Menurut Wanda \& Pangestuti (2018), akses jalan raya, ketersediaan sarana transportasi dan rambu-rambu penunjuk jalan merupakan aspek penting bagi sebuah destinasi. Apabila ketiga aspek tersebut terpenuhi maka destinasi tersebut sesuai untuk dijadikan destinasi wisata. Berdasarkan hasil analisis aksesibilitas Pulau Terkulai adalah memenuhi 1 aspek atau ketentuan tersebut yang terkategori sesuai bersyarat (S3) untuk dijadikan kawasan wisata pantai dengan adanya akses jalan raya yang dapat dilalui dengan kondisi baik untuk menuju Pelabuhan ke Pulau Terkulai dan tidak adanya transportasi laut umum yang bisa digunakan pengunjung serta tidak adanya rambu-rambu penunjuk jalan menuju Pulau Terkulai (Gambar 5).

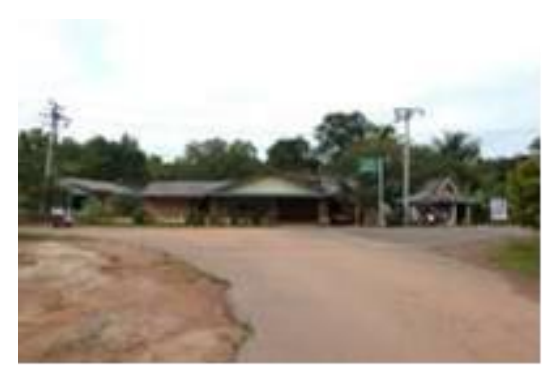

Akses jalan raya

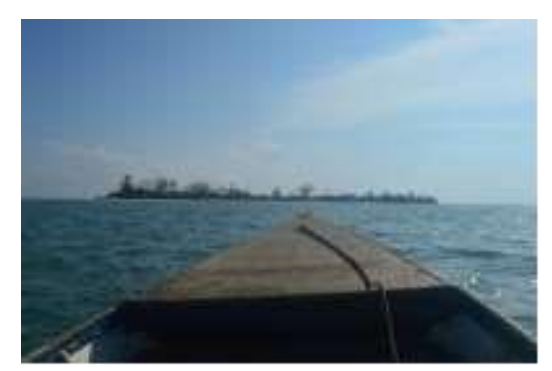

Transportasi laut

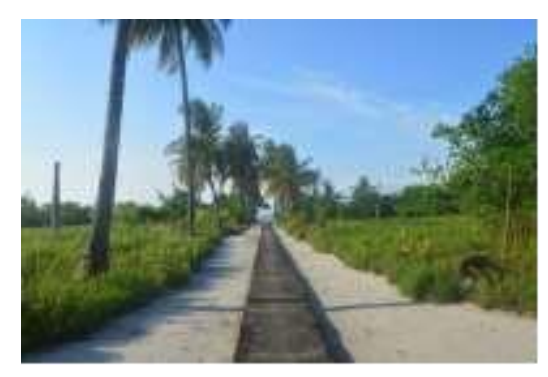

Akses jalan di Pulau Terkulai

Gambar 5. Aksesibilitas Pulau Terkulai 


\subsubsection{Sarana dan Prasarana Pulau Terkulai}

Sarana dan prasarana perlu untuk disediakan di daerah tujuan wisata untuk mewujudkan sebuah kawasan wisata yang baik yang mampu menarik minat dari pengunjung. Sarana dan prasarana dilihat dari 3 ketentuan yaitu akomodasi, tempat makan dan minum serta fasilitas umum (Fajriah \& Masadun, 2014). Berdasarkan hasil analisis sarana dan prasarana Pulau Terkulai tidak memenuhi 3 ketentuan sebagai pendukung aktivitas wisata pantai yang terkategori $\mathrm{N}$ atau tidak sesuai untuk kegiatan wisata dengan skor 0 yaitu kondisi parameter dengan kualitas buruk. Kondisi seperti ini memiliki faktor pembatas yang dapat mengurangi kepuasan pengunjung dan perlu adanya implikasi pengelolaan demi menunjang aktivitas wisata pantai karena dalam mewujudkan sebuah kawasan wisata yang baik, berbagai sarana dan prasarana wisata yang harus disediakan di daerah tujuan wisata (Perdana et al., 2016).

\subsubsection{Penutupan Lahan Pantai}

Jenis penutupan lahan pantai di Pulau Terkulai adalah belukar tinggi yang terkategori sesuai bersyarat (S3), dimana kategori tersebut merupakan faktor pembatas yang dapat mengurangi kepuasan pengunjung, maka perlu adanya pengelolaan pada kawasan tersebut (Gambar 6). Penutupan lahan pantai dapat direhabilitasi dengan cara melakukan pembabatan pada semak belukar rendah dan tinggi, sehingga kesesuaian wisata menjadi sangat sesuai dan dapat mendukung kegiatan wisata pantai.

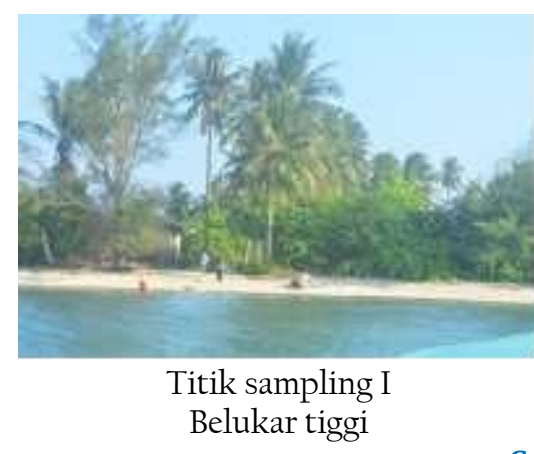

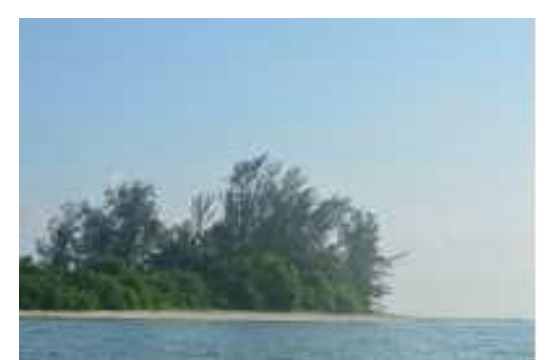

Titik sampling II Belukar tiggi

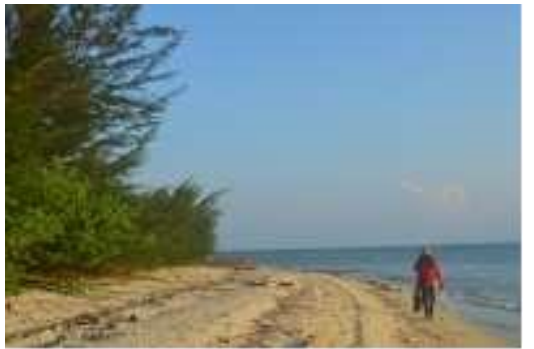

Titik sampling III Belukar tiggi

Gambar 6. Penutupan Lahan Pantai Pulau Terkulai

Jenis vegetasi yang diidentifikasi pada ketiga titik sampling terdapat 11 jenis vegetasi. Jenis vegetasi ter sebut dapat dilihat pada Tabel 5.

Tabel 5. Identifikasi Vegetasi Penutupan Lahan Pantai Pulau Terkulai

\begin{tabular}{|c|c|c|c|c|c|}
\hline \multirow{2}{*}{ No } & \multicolumn{2}{|c|}{ Jenis Vegetasi } & \multicolumn{3}{|c|}{ Titik Sampling Pengukuran } \\
\hline & Nama Ilmiah & Nama Lokal & Sampling I & Sampling II & Sampling III \\
\hline 1 & Ipomoea pescaprae & Tapak kuda & & & $\sqrt{ }$ \\
\hline 2 & Pandanus tectorius & Pandan & & $\sqrt{ }$ & \\
\hline 3 & Scaevola taccada & Bakung-bakung & $\sqrt{ }$ & $\sqrt{ }$ & $\sqrt{ }$ \\
\hline 4 & Sesuvium portulacastrum & Saruni air & & & $\sqrt{ }$ \\
\hline 5 & Terminalia catappa & Ketapang & & $\sqrt{ }$ & \\
\hline 6 & Morinda citrifolia & Mengkudu & $\sqrt{ }$ & & \\
\hline 7 & Casuarina equisetifolia & Cemara Laut & $\sqrt{ }$ & $\sqrt{ }$ & \\
\hline 8 & Cocos nucifera & Kelapa & $\sqrt{ }$ & & \\
\hline 9 & Asplenium adiantumningrum & - & $\sqrt{ }$ & & \\
\hline 10 & Brachiaria decumbens & Rumput signal & $\sqrt{ }$ & & $\sqrt{ }$ \\
\hline 11 & Pueraria lobate & Kudzu & & & $\sqrt{ }$ \\
\hline
\end{tabular}

Sumber: Data Primer (2018)

\subsubsection{Ketersediaan Air Tawar}

Saat melakukan kegiatan wisata, ketersediaan air bersih berupa air tawar sangat diperlukan untuk menunjang fasilitas pengelolaan maupun pelayanan wisata (Yulisa, 2016). Berdasarkan hasil pengamatan tidak dit emukan ketersediaan air tawar yang dapat diakses secara umum oleh pengunjung sehingga terkategori tidak sesuai (N) dengan kondisi parameter yang berkualitas buruk. Ketersediaan air tawar berhubungan dengan kebersihan bagi pengunjung yang melakukan aktivitas wisata pantai yang dapat mempengaruhi kepuasan pengunjung karena air tawar diperlukan untuk membersihkan diri seusai melakukan aktivitas di pantai. Tidak adanya ketersediaan air tawar merupakan suatu faktor pembatas untuk melakukan aktivitas pantai dan perlunya implikasi pengelolaan yang baik untuk mendukung aktivitas wisata pantai.

\subsection{Tingkat Kesesuaian Kawasan Wisata Pantai Pulau Terkulai}

Pulau Terkulai memiliki karakteristik yang hampir sama antara titik sampling satu dengan yang lainnya. Hal tersebut dapat dilihat dari hasil persentase kesesuaian wisata yang hasilnya tidak berbeda jauh antara titik sampling satu dengan yang lainnya, hal itu dikarenakan jarak antar titik sampling pengukuran parameter hanya sekitar \pm 200 meter, oleh karena itu hasil penelitian di lapangan dari paremeter yang diukur tidak jauh berbeda antara titik sampling 
pengukuran parameter. Hasil analisis kesesuaian kawasan wisata pantai pada titik sampling I, II dan III dari 12 parameter potensi ekologi yang telah diukur dan data yang diolah dimasukkan ke dalam matriks kesesuaian wisata pantai secara lengkap dapat dilihat pada Tabel 6.

Tabel 6. Tingkat Kesesuai Kawasan Wisata Pantai di Pulau Terkulai

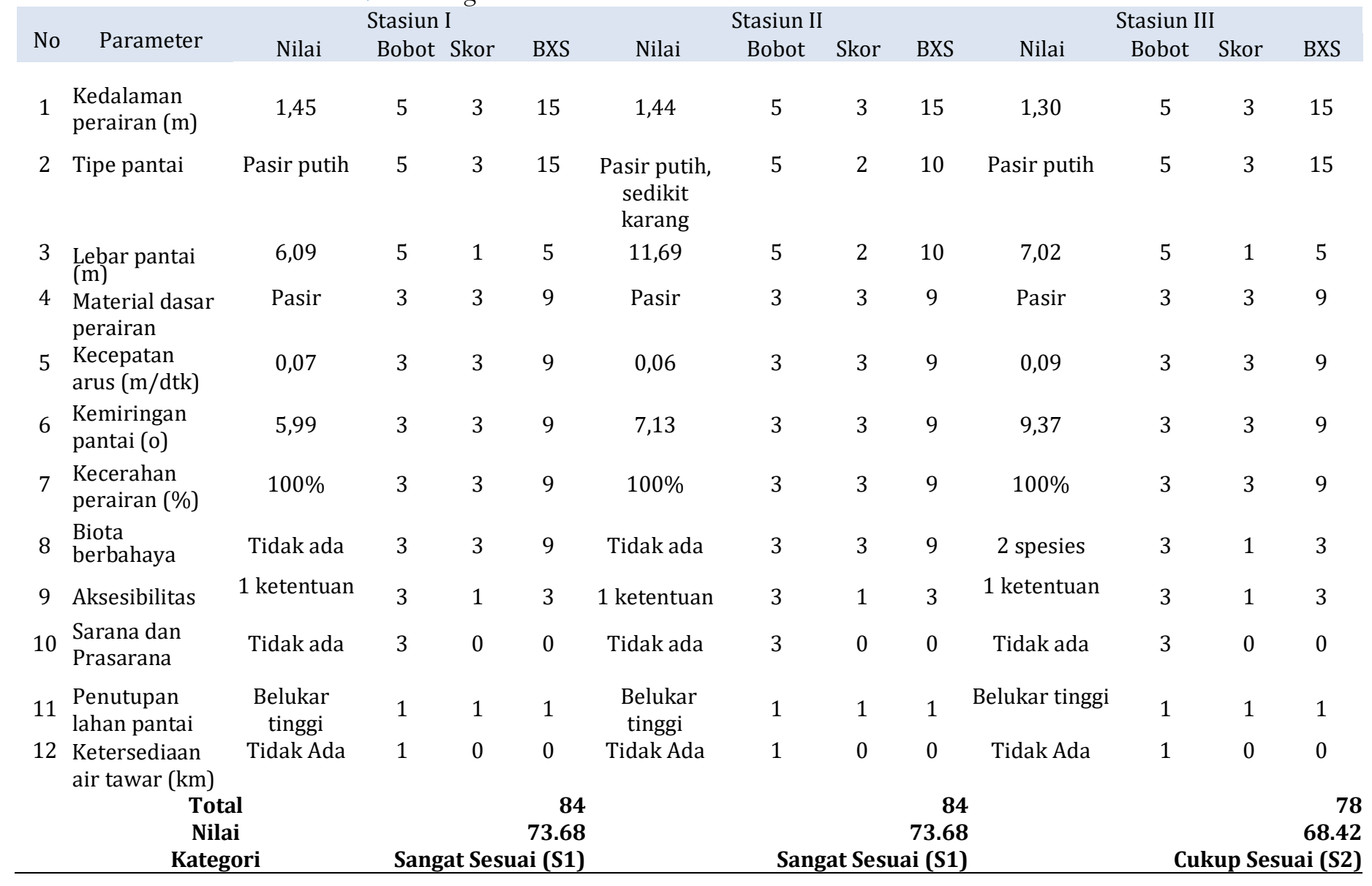

Pada titik sampling III kategori S2 dapat diartikan sebagai kawasan ekosistem pantai yang cukup sesuai untuk dimanfaatkan sebagai kawasan wisata pantai. Faktor pembatas yang agak berat untuk suatu penggunaan kegiatan tertentu secara lestari. Faktor pembatas tersebut akan mempengaruhi kepuasan dalam kegiatan wisata sehingga diperlukan upaya tertentu dalam pengelolaan ekosistem pantai tersebut. Sedangkan pada titik sampling I dan II kategori Sl dapat diartikan sebagai kawasan ekosistem pantai yang sangat sesuai untuk dimanfaatkan sebagai kawasan wisata pantai, tidak mempunyai faktor pembatas yang berat atau hanya mempunya faktor pembatas yang kurang berarti terhadap kondisi kawasan dan tidak terlalu memerlukan masukan untuk pengembangannya sebagai objek kawasan wisata pantai. Berdasarkan hasil wawancara terhadap masyarakat juga menunjukkan, Pulau Terkulai yang memiliki kawasan pantai yang menarik dan sesuai untuk dijadikan sebagai kawasan wisata pantai namun, pada parameter sarana dan prasarana serta aksesibilitas tidak memadai. Melihat dari hasil tersebut, perlu untuk diambil kebijakan lebih lanjut mengenai pengelolaan kawasan untuk dijadikan kawasan wisata pantai didukung oleh potensi ekologi yang ada demi kenyamanan dan keamanan bagi para pengunjung. Hasil analisis ini memungkinkan dapat dilakukan berbagai aktivitas wisata pantai meliputi renang, berjemur, bermain air, bermain pasir dan menikmati pemandangan (Lalloterry et al., 2016).

\subsection{Daya Dukung Kawasan}

Daya dukung menunjukkan jumlah maksimum pengunjung yang secara fisik dapat ditampung di kawasan yang tersedia pada waktu tertentu tanpa menimbulkan gangguan pada alam dan manusia. Pantai Pulau Terkulai memiliki luas sekitar 58,592 a atau 5859,3 m2 yang dapat dimanfaatkan pada kawasan Pulau Terkulai. Nilai ini didapat dari hasil perhitungan luas area kesesuaian untuk wisata rekreasi pantai (polygon) menggunakan perangkat lunak field area measure. Hasil analisis daya dukung kawasan wisata pantai Pulau Terkulai disajikan pada Tabel 7.

Berdasarkan data tersebut didapat nilai daya dukung kawasan pantai Pulau Terkulai adalah 234,4 atau 234 jiwa. Hal ini menunjukkan bahwa jumlah pengunjung yang dapat ditampung pada kawasan pantai Pulau Terkulai dengan tetap memperhatikan kenyamanan dan kelestarian kawasan adalah kurang lebih 234 jiwa dengan pemanfaatan luas area $50 \mathrm{~m}$ /orang untuk waktu kunjungan selama 3 jam/orang/hari. Nilai daya dukung kawasan tersebut akan menjadi acuan jika Pulau Terkulai akan dijadikan sebagai kawasan wisata pantai. Jumlah daya dukung kawasan tersebut memerlukan fasilitas pendukung seperti sarana dan prasarana, aksesibilitas dan ketersediaan air tawar sebagai faktor pembatas yang perlu dikelola berdasarkan hasil wawancara persepsi masyarakat. 
Tabel 7. Analisis daya dukung kawasan wisata pantai Pulau Terkulai

\begin{tabular}{llll} 
No & \multicolumn{1}{c}{ Variabel } & \multicolumn{1}{c}{ Satuan } & Nilai \\
1 & Pengunjung (K) & Jiwa & 1 \\
2 & Luas Area Pantai (Lp) & $\mathrm{m}^{2}$ & 5859,3 \\
3 & Unit Area (Lt) & $\mathrm{m}^{2}$ & 50 \\
4 & Waktu Kunjungan (Wp) & Jam/orang & 3 \\
5 & Waktu Tersedia (Wt) & Jam & 6 \\
6 & Daya Dukung Kawasan (DDK) & Jiwa & 234,4 \\
\hline
\end{tabular}

Sumber: Data Primer (2018)

\section{SIMPULAN}

Kesimpulan dari penelitian yang dilakukan pada Pulau Terkulai dalam analisis kesesuaian kawasan wisata pantai adalah: Potensi ekologis pada 12 parameter secara umum sangat sesuai pada parameter kedalaman, material dasar perairan, kecepatan arus, kemiringan pantai dan kecerahan perairan. Pada parameter tipe pantai, lebar pantai, aksesibilitas, serta penutupan lahan pantai dterkategori cukup sesuai dan sesuai bersyarat. Pada parameter ketersediaan air tawar dan sarana dan prasarana yaitu tidak sesuai dengan skor 0. Indeks Kesesuaian Wisata (IKW) pada titik sampling I dan II menunjukkan bahwa Pulau Terkulai sangat sesuai (SI) untuk dijadikan sebagai kawasan wisata pantai dengan tingkat kesesuaian yaitu 73,68\%, sedangkang pada titik smapling III menunjukkan cukup sesuai dengan tingkat kesesuaian yaitu 68,42\%. Kawasan pantai Pulau Terkulai memiliki Daya Dukung Kawasan (DDK) untuk kegiatan wisata pantai yaitu 234 Jiwa dengan pemanfaatan luas area $50 \mathrm{~m}$ /orang untuk waktu kunjungan selama 3 jam/orang/hari.

Adapun saran berdasarkan hasil penelitian yang menunjukkan Pulau Terkulai yang berpotensi untuk dijadikan sebagai kawasan wiata patai dengan waktu penelitian yang terbatas, maka perlu adanya penelitian lebih lanjut tentang pengembangan kawasan wisata pada Pulau Terkulai. Perlu adanya pembangunan sarana dan prasarana untuk menunjang aktivitas wisata dan tersedianya aksesibilitas.

\section{UCAPAN TERIMA KASIH}

Penulis mengucapkan terimakasih kepada pihak-pihak yang telah memberikan masukan dan bimbingan yaitu kepada Dosen Pembimbing yaitu Dr. Febrianti Lestari, S.Si., M.Si dan Dedy Kurniawan, S.Pi., M.Si.

\section{REFERENSI}

Badan Perencanaan Pembangunan Daerah. (2016). Sektor Pariwisata Peluang Invertasi. [internet]. [diacu 15 Maret 2018]. Tersedia di http//:bappeda.kepri.go.id/index.php/data-informasi/potensi-daerah/47-potensi-daerah/207-sektor-pariwisata.

Chasanah, I., Purnomo, P.W., \& Haeruddin. (2017). Analisis Kesesuaian Wisata Pantai Jodo Desa Sidorejo Kecamatan Gringsing Kabupaten Batang. Jurnal Pengelolaan Sumberdaya Alam dan Lingkungan, 7( 3): 235-243.

Fajriah, S.D., \& Massadun. (2014). Pengembangan Sarana dan Prasarana untuk Mendukung Pariwisata Pantai yang Berkelanjutan (Studi Kasus: Kawasan Pesisir Pantai Wonokerto Kabupaten Pekalongan). Jurnal Pembangunan Wilayah dan Kota, 10 2): 218-233.

Febyanto, F., Praktikto, I., \& Koesoemadji. (2014). Analisis Kesesuaian Wisata Pantai di Pantai Krakal Kabupaten Gunungkidul. Jurnal of Marine Research, 3 (4): 429-438.

Habibi, A., Adi, W., \& Syari, A.I. (2017). Kesesuaian Wisata Pantai untuk Rekreasi di Pulau Bangka. Jurnal Sumberdaya Perairan, ll(1): 54-60.

Juliana. (2013). Kesesuaian dan Daya Dukung Wisata Bahari di Perairan Bandengan Kabupaten Jepara Jawa Tengah. Jurnal Perikanan dan Ilmu Kelautan, 9(1): 11-23.

Kamah, M.H., Sahami, F.M., \& Hamzah, S.N. (2013). Kesesuaian Wisata Pantai Berpasir Pulau Saronde Kecamatan Pondo Kepulauan Kabupaten Gorontalo Utara. Jurnal Ilmu-Ilmu Pertanian, 1(1): 1-15.

Karnanda, K., Lestari, F., \& Kurniawan, D. (2019). Analisis Kesesuaian Kawasan Perairan Pulau Bungin untuk Ekowisata Snorkeling di Kecamatan Tambelan Kabupaten Bintan. Jurnal Pengelolaan Perairan, 2(1): 1-10.

Lelloterry, H., Pujiatmoko, S., Fandelli, C., \& Baiquni, M. (2016). Pengembangan Ekowisata Berbasis Kesesuaia n dan Daya Dukung Kawasan Pantai (Studi Kasus Pulau Marsegu Kabupaten Seram Bagian Barat). Jurnal Budidaya Pertanian, 12(1): 25-33.

Lestari, L.H. (2013). Komparasi Karakteristik Pantai Peneluran Penyu (Kasus Pantai Pengumbahan dan Sindang Kerta Jawa Barat). Universitas Padjajaran.

Mizan, A., Lestari, F., \& Susiana. (2018). Tingkat Kesesuaian dan Daya Dukung Wisata Pantai di Pulau Penjalin, Kabupaten Kepulauan Anambas. Jurnal Akuatiklestari, 2(1): 1-8. https://doi.org/10.31629/akuatiklestari.v2il.919

Noor, Y.R., Khazali, M., \& Suryadiputra, N.N. (2006). Panduan Pengenalan Mangrove di Indonesia. PHKA/WI -IP. Bogor.

Perdana, I.B., Suasti, Y., \& Ahyuni. (2016). Identifikasi Potensi Fisik Pesisir Pantai Wisata Bahari Kelurahan Teluk Kabung Selatan Kecamatan Bungus Teluk Kabung Kota Padang. Jurnal Geografi, 5(2): 123-130.

Subandi, I.K., Dirgayusa, I.G.N.P., \& Asy-syakur, A.R. 2018. Indeks Kesesuaian Wisata di Pantai Pasir Putih Kabupaten Karangasem. Journal of Marine and Aquatic Sciences, 4(1): 47-57.

Wanda, I.B.K., \& Pangestuti, E. 2018. Pengaruh Pengembangan Komponen Destinasi Wisata terhadap Kepuasan Pengunjung (Survei pada Pengunjung Situs Trowulan). Jurnal Adnministrasi Bisnis (JAB), 55(3): 83 -91. 
Yulianda, F. (2007). Ekowisata Bahari sebagai Alternatif Pemanfaatan Sumberdaya Pesisir Berbasis Konservasi. Makalah Seminar Sains pada Departemen Manajemen Sumberdaya Perairan. Fakultas Perikanan dan Ilmu Kelautan, Institut Pertanian Bogor (IPB). Bogor.

Yulianda, F., A. Fahrudin, A.A. Hutabarat, S. Harteti, Kusharjani, H.S. Kang, \& L. Adrianto. (2010). Pengelolaan Pesisir dan Laut secara Terpadu. Pusdiklat Kehutanan-Departemen Kehutanan RI, SECEM-Korea International Cooperation Agency. Bogor.

Yulisa, E.N., Johan, Y., Hartono, D. (2016). Analisis Kesesuaian dan Daya Dukung Ekowisata Pantai Kategori Rekreasi Pantai Laguna Desa Merpas Kabupaten Kaur. Jurnal Enggano, 1(1): 97-111.

Yusuf, M. (2007). Kebijakan Pengelolaan Sumberdaya Pesisir dan Laut Kawasan Taman Nasional Karimunjawa secara Berkelanjutan. Buletin Ekonomi Perikanan, 4(2): 86-98. 